Available online at GSC Online Press Directory

GSC Biological and Pharmaceutical Sciences

e-ISSN: 2581-3250, CODEN (USA): GBPSC2

Journal homepage: https://www.gsconlinepress.com/journals/gscbps

(RESEARCH ARTICLE)

\title{
Bioactivities of forest medicinal plants on kutai ethnic (Indonesia) of tapak leman (Hippobroma longiflora (L) G. Don)
}

\author{
Zarta Abdul Rasyid 1, ${ }^{*}$, Aryani Farida 2, Salusu Heriad Daud ${ }^{3}$, Suwinarti Wiwin ${ }^{4}$, Kusuma Irawan Wijaya 4 \\ and Arung Enos Tangke 4 \\ ${ }^{1}$ Wood Engineering Department, Samarinda State Agriculture Polytechnic, Samarinda, East Kalimantan, Indonesia. \\ 2 Plantation Technology Department, Samarinda State Agriculture Polytechnic, Samarinda, East Kalimantan, Indonesia. \\ ${ }^{3}$ Forest Product Processing Department, Samarinda State Agriculture Polytechnic, Samarinda, East Kalimantan, \\ Indonesia. \\ ${ }^{4}$ Faculty of Forestry, University of Mulawarman, Samarinda, East Kalimantan.
}

Publication history: Received on 01 May 2020; revised on 07 May 2020; accepted on 09 May 2020

Article DOI: https://doi.org/10.30574/gscbps.2020.11.2.0125

\begin{abstract}
Indonesian forests are one of the richest ecosystems in the world. Secondary metabolites with molecular structures and various biological activities of medicinal plant extracts have excellent potential to be developed into medicines of various diseases. Phenolic compounds found in plants have many biological effects including antioxidants and antimicrobials. Secondary metabolite compounds play a protective role against damage caused by disease. Traditional medicine and treatment among the people of Kutai Kartanegara is very diverse and has been widely used. Type of Tapak Leman (Hippobroma longiflora (L) G. Don) is one type of forest plants have been used as a medicinal plant by Ethnic Kutai with the efficacy of treatment of kidney stones and increase of stamina or vitality. The aim of study is to investigate the biological activity of Tapak Leman forest type that had been used as medicine. The leaves of the plant samples were extracted using ethanol and then extracts tested phytochemical content, toxicity, biological activity of antioxidant and antimicrobial. Testing of antioxidant activity by spectrophotometric method using DPPH (1,1-diphenyl-2picrylhydrazyl), the level of toxicity using by BSLT (Brine Shrimp Lethality Test), and antimicrobials by diffusion method. The results showed is Tapak Leman type has a phytochemical content of alkaloids, flavonoids, tannins, saponis and steroids. Type of Tapak Leman properties is toxic, has strong antioxidant and strong on fungi.
\end{abstract}

Keywords: Phytochemical; Toxicity; Antioxidant; Antibacterial

\section{Introduction}

Forests in Indonesia are one of the ecosystems that have the largest species richness in the world. Indonesian forests contain more than 400 species of trees of high economic value and approximately 25,000 species of flowering plants [1].

The development of new types of diseases has increased from year to year, and many drugs currently circulating are no longer able to cope with these new diseases. Therefore the search for new types of drugs still continues at any time [2].

Plant ingredients contain various forms of antioxidants. Phenolic compounds are found in plants, have many biological effects. Flavonoids and other phenolics play a protective role against damage caused by disease [3, 4]. Secondary metabolites with diverse molecular structures and biological activities derived from medicinal plant forest extracts have excellent potential to be developed into various diseases. However, the level of herbal production in general is still

\footnotetext{
${ }^{*}$ Corresponding author: Zarta Abdul Rasyid
} 
limited, mainly due to the lack of scientific information about the efficacy of a plant species. In order to support aspects of the use of traditional medicines that have developed in the community, scientific proof is needed so that the herbal medicine industry in Indonesia is growing [5].

Traditional medicine and medicine among the people of Kutai Kartanegara are very diverse. Various kinds of drugs and treatments can be classified into two types, namely drugs and traditional treatments for internal and external illness or disease. In addition to traditional medicine and medicine, the Kutai people also know various kinds of traditional healers and medical experts [6].

The purpose of this study was to identify the bioactivity of medicinal plants from forest plants that have been traditionally used by the Kutai people by looking at phytochemical content, toxicity, antioxidant antimicrobial activity.

\section{Material and methods}

\subsection{Reagent}

Ethanol; acetone; dimethyl sulfoxide (DMSO); 1,1-diphenyl-2-picrylhydrazyl radical (DPPH); ascorbic acid; reactants for Dragendorff's test, Liebermann-Burchard test, and Molisch test; potassium dichromate $\left(\mathrm{K}_{2} \mathrm{Cr}_{2} \mathrm{O}_{7}\right)$; Nutrient Broth medium (NB); and the antibiotic ChloramphenicolEthanol; acetone; dimethyl sulfoxide (DMSO); 1,1-diphenyl-2picrylhydrazyl radical (DPPH); ascorbic acid; reactants for Dragendorff's test, Liebermann-Burchard test, and Molisch test; potassium dichromate $\left(\mathrm{K}_{2} \mathrm{Cr}_{2} \mathrm{O}_{7}\right)$; Nutrient Broth medium (NB); and the antibiotic Chloramphenicol

\subsection{Plant material extraction}

Plant materials in the form of leaves of Nek Kara (Hippobroma longiflora (L) G. Don) were collected from Sebulu Modern Village, Kutai Kartanegara regency, in East Kalimantan province, Indonesia. The plant materials were dried at room temperature and ground into a powder [7]. The dried plants material were extracted in ethanol at room temperature for 48 hours. Then the extracts were filtered, and the concentrates were prepared by using a rotary vacuum evaporator at a temperature of $30-40^{\circ} \mathrm{C}$.

\subsection{Phytochemical analysis}

Phytochemical analyses were performed for detection of alkaloids, flavonoids, and tannins [8], as well as for steroids, saponins, and triterpenoids [9].

\subsection{Toxicity testing}

Toxicity testing of the plant extracts used the Brine Shrimp Lethality Test (BSLT) described by Meyer [10]. The BSLT method is widely used to obtain an approximate measure of bio-activity of plant materials with suspected medicinal application. These methods are easy to perform, are inexpensive, fast, and able to be used with small amounts of plant extract [10]. The BSLT method is also widely used for screening new potential anticancer compounds derived from plants. The results of toxicity tests using this method have demonstrated a correlation with cytotoxic anti-cancer activity. $\mathrm{LC}_{50}$ is defined as the concentration of a compound that is expected to kill $50 \%$ of a test population within a given time interval [11]. Determination of the level of toxicity used the aquatic toxicity criteria defined by Wagner [12].

\subsection{Analysis of antioxidant activity}

The investigation of antioxidant activity was carried out using the method of Arung [13]. A spectrophotometer was used at temperature room $\left(25^{\circ} \mathrm{C}\right)$ and $514 \mathrm{NM}$ wavelength. DPPH solution (1,1-diphenyl-1-picrylhydrazyl radical), as well as ascorbic acid (Vitamin C), were used as positive controls. The concentration of the sample extract needed to achieve inhibition of $50 \%$ was expressed as the $\mathrm{IC}_{50}$ value for the extract. There were three replicate analyses per extract and the results were averaged. Determination of the antioxidant activity of the extracts using the DPPH method was carried out according to Jun [14].

\subsection{Anti-bacterial testing}

The antimicrobial test was performed by the diffusion method described by Cappucino and Sherman [15], with some modification. In this test, $20 \mathrm{ml}$ of Nutrient Broth medium (NB) was poured into a sterilized petri dish. After that, the media was hardened and flattened using a cotton swab, in an aseptic state (using laminar flow). The media were allowed to dry for approximately 30 minutes. Hole wells were made using a cork borer applied to the media. The wells contained $20 \mu \mathrm{L}$ with different amounts of extract: $25 \mu \mathrm{g}$ / well, $50 \mu \mathrm{g}$ / well, $100 \mu \mathrm{g}$ / well and $200 \mu \mathrm{g} /$ well. Chloramphenicol 
was used as a positive control. Bacterial incubation was performed for 24 hours, and then the inhibition zone was measured around the wells in each petri dish.

\section{Results and discussion}

\subsection{Traditional medicine of the Kutai Ethnic community}

Among the Kutai ethnic community of Desa Sebulu Modern, in Kutai Kartanegara Regency of East Kalimantan, there is traditional knowledge of medical treatments based on medicinal herbs growing in their forest vegetation. This knowledge has been inherited from their ancestors and has been preserved from generation to generation. However, not everyone is expert in the types of forest plants that can be used as herbal medicines. Only certain people have this kind of ability and such persons are usually acknowledged for their expertise in concocting medicinal cures.

Based on information and discussions with such traditional healers in the Kutai ethnic communities, each generation attempts to develop the knowledge gained from their ancestors. This includes knowledge about the forest vegetation in general, but also of methods used in concocting medicines by way of mashing, dissolving and boiling specific herbs. Such methods sometimes make people reluctant to consume herbal medicines because the aromas are often pungent and the tastes bitter.

The types of medical conditions that are treated with herbal medicines from the forests range from mild ailments such as flu, colds, cough, headaches, and stomach pain through to serious disease conditions such as cancer, strokes, heart attacks, hypertension, constriction of blood vessels, stomach injuries, kidney stones, and others.

The results of identification and description of Hippobroma longiflora (L) G. Don plant species utilized by the Kutai community in Desa Sebulu Modern for such traditional medical purposes are summarized in Table 1.

Table 1 Identification, Utilization and Description of Hippobroma longiflora (L) G. Don Type.

\begin{tabular}{llll}
\hline $\begin{array}{l}\text { Local name/ Scientific } \\
\text { name/ Family }\end{array}$ & $\begin{array}{l}\text { Plant } \\
\text { part } \\
\text { used }\end{array}$ & $\begin{array}{l}\text { Traditional } \\
\text { utilization }\end{array}$ & Plant description \\
\hline $\begin{array}{l}\text { Tapak Leman/ } \\
\text { Hippobroma longiflora }\end{array}$ & Leaf & $\begin{array}{l}\text { Treatment of kidney stones } \\
\text { and increase of stamina or } \\
\text { vitality }\end{array}$ & $\begin{array}{l}\text { Bush plants on wet areas. } \\
\text { Has a long flower stalk. The } \\
\text { crown is star-shaped. }\end{array}$ \\
Campanulaceae & & & \\
\hline
\end{tabular}

The plants of Tapak Leman can be seen in Figure 1 below.

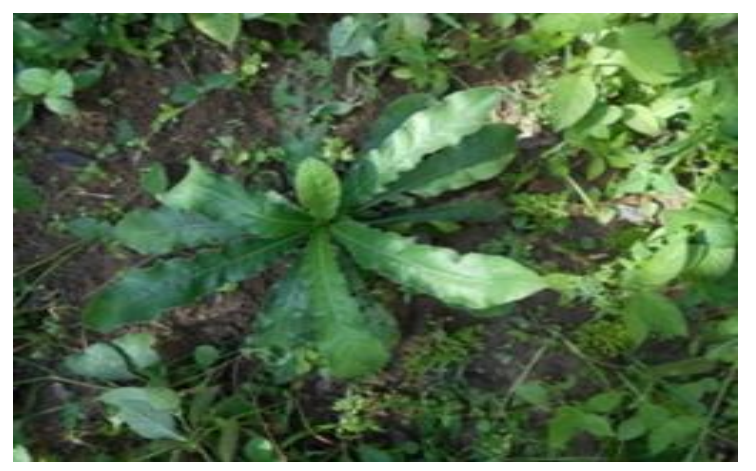

Figure 1 Plants of Tapak Leman (Hippobroma longiflora (L) G. Don). 


\subsection{Extraction result and phytochemical content}

The preliminary extraction method for bioactivity testing used in this research is cold maceration method using ethanol solvent at room temperature. The use of this solvent aims to attract the active components contained in the raw material of the medicinal plant.

The plant leaves powder was soaked for $2 \times 24$ hours, then filtered and concentrated until a crude extract was obtained. The yield calculation is done to find out how many parts can be extracted from the sample to be tested. The factors such as water content, sample size, solvent and extraction techniques greatly influence the extract yield value obtained from the extraction results in a test sample [9]. This percentage of yield will affect the amount of extracted weight from a number of raw materials used. The higher the yield obtained, indicates that the weight of the extract produced is increasing.

Phytochemical testing of plant materials is used to identify secondary metabolite compounds. Such compounds while not a requirement for normal body function, are often found on evaluation to have positive effects on human health and can play an active role in prevention and treatment of disease. The plant extracts prepared from Tapak Leman type, secondary metabolite compounds included alkaloids, flavonoids, tannins, saponins, steroids. The presence of these phytochemical compounds in the plant materials suggests the potential medicinal value of their extracts in the prevention and/or cure of specific diseases.

The specific results of extract and phytochemical analyses, listed in Table 2

Table 2 Medicinal Plant Extracts Yield of Hippobroma longiflora (L) G. Don with Ethanol Solvents and Phytochemical Content.

\begin{tabular}{llllr}
\hline $\begin{array}{l}\text { Powder weight } \\
\text { OD } \mathbf{( g )}\end{array}$ & $\begin{array}{l}\text { Extract } \\
\text { weight } \mathbf{( g )}\end{array}$ & $\begin{array}{l}\text { Yield } \\
\text { (\%) }\end{array}$ & $\begin{array}{l}\text { Phytochemical } \\
\text { contents }\end{array}$ \\
\hline 26.02 & 0.99 & 3.83 & $\begin{array}{l}\text { Alkaloids, } \\
\text { Tannins, } \\
\text { Steroids }\end{array}$ & $\begin{array}{r}\text { Flavonoids, } \\
\text { Saponis, }\end{array}$ \\
\hline
\end{tabular}

Flavonoids were found in the medicinal plant species tested. In general, flavonoids can function as antioxidants which inhibit possible metabolic damage by free radicals [16]. All these potential medicinal plants showed antioxidant activity (see the next Section). The presence of flavonoids and tannins in plants has been found to play a role in binding free radicals. Flavonoids and tannins are phenolic compounds, and phenolics, in general, are a group of compounds that act as primary antioxidants in binding free radicals in plant metabolic pathways [17].

In biological systems, flavonoids have antioxidant activity; inhibiting free radicals, and in some cases having anti-allergic effects with reduction in inflammation and platelet aggregation. There are also reports of anti-microbial effects, and inhibition of ulcers, tumors, and hepatoxicity [18]. In general, phytochemical analysis of plants with suspected medicinal benefits is a fruitful area of research for identifying physiologically active compounds with the ability to protect the human body from the effects of various kinds of metabolic damage arising from both internal and external factors [19].

\subsection{Toxicity}

The toxicity testing of the plant samples aimed at finding out whether the samples contain a toxin or not. The brine shrimp Artemia nauplii has been suggested to be used as a model species in some evaluations of the pharmacological activity of ecotoxins and large complex compounds [20,21]. In our toxicity testing, we used the related shrimp species Artemia salina, Linnaeus. Initial tests were carried out with the extracts to see if at concentration of 1000 ppm the extracts would kill the shrimp larvae. In this preliminary test, these sample extracts at that concentration resulted in a shrimp larvae mortality of $50 \%$ or more.

According to Meyer [10], a plant extract is considered to have toxic activity if it is able to kill more than 50\% Artemia larvae at a concentration of $1000 \mathrm{ppm}$. Therefore we went on to test in more detail the toxic activity of three plant extracts. We evaluated their toxic effect at lower concentrations i.e. at 500 ppm, 250 ppm, 100 ppm and 10 ppm. The results are displayed in Table 3 . 
Table 3 Evaluation of the toxicity of Hippobroma longiflora (L) G. Don extracts.

\begin{tabular}{lllll}
\hline $\begin{array}{l}\text { Concentrations } \\
\text { (ppm) }\end{array}$ & $\begin{array}{l}\text { Average of } \\
\text { mortality }\end{array}$ & $\begin{array}{l}\text { \% } \\
\text { Mortality }\end{array}$ & $\begin{array}{l}\text { LC50 } \\
\text { (ppm) }\end{array}$ & Remark \\
\hline 1000 & 6.0 & 60 & 423 & Toxic \\
500 & 5.7 & 57 & & \\
250 & 3.3 & 33 & & \\
100 & 2.3 & 23 & & \\
10 & 1.0 & 10 & & \\
\hline
\end{tabular}

The higher concentrations of the extracts in solution, the higher was the percentage mortality in the test larvae. The trends in percent increase in mortality (\%) in response to increase in extract concentration (ppm) were analyzed by liner regression to obtain estimates of the $\mathrm{LC}_{50}$ for the sample extracts. The results of the calculation of LC 50 values indicate that samples extracted from Tapak Leman type was assessed to be toxic. These findings are of significance because if concoctions extracted from these species are being used in traditional medicines by the Kutai communities, then it needs to be determined whether it is safe for human consumption irrespective of potential benefits such as antioxidant activity of their phytochemical compounds. No complaints have so far been voiced against use of these materials as ingredients in the Kutai traditional medicine. Based on this fact, it is suspected that the toxic effects of the extracts on Artemia shrimps possibility do not extend to harmful effects on humans. It can be explained that toxicity testing using the BSLT method using Artemia salina Leach shrimp seed. is a method in addition to knowing the level of toxicity of a particular substance also provides an illustration that a type of plant that is toxic means that it has the potential of activity as an anticancer and is not necessarily toxic to humans. According to the provisions set forth by McLaughin [22] which conveyed LC50 values $<30$ ppm extract potentially as anticancer.

\subsection{Antioxidant activity}

Natural resources, especially plants, are an important part of the search for new sources of raw materials as natural antioxidant agents. In our investigation of the antioxidant activity of extracts from Tapak Leman plants, the free radical scavenging effect of the fractions at different concentrations was measured by DPHH assay using a spectrophotometric determination of absorbance at a wavelength of $517 \mathrm{~nm}[14,23,24,25]$.

The $\mathrm{IC}_{50}$ value (the concentration required to obtain a $50 \%$ inhibition) was employed as the parameter to express the relative antioxidant capacity of the different plant extracts. The antioxidant effectiveness of a plant extract is judged to be strong if it has a value of $\mathrm{IC}_{50}<50 \mathrm{ppm}$. Estimates of the $\mathrm{IC}_{50}$ values, shown in Table 4 , were obtained by linear regression analysis of the trend in $\%$ inhibition in response to increasing concentration of the extracts.

Table 4 The Results of Antioxydant Testing of Hippobroma longiflora (L) G. Don.

\begin{tabular}{lllll}
\hline $\begin{array}{l}\text { Concentration } \\
\text { (ppm) }\end{array}$ & $\begin{array}{l}\text { Inhibition } \\
\text { (\%) }\end{array}$ & $\begin{array}{l}\text { Regression } \\
\text { Equation }\end{array}$ & $\begin{array}{l}\text { IC50 } \\
\text { (ppm) }\end{array}$ & Remark \\
\hline 1.562 & 8.75 & $\mathrm{Y}=4.8471 \mathrm{x}+8$ & Strong \\
3.125 & 34.39 & 10.815 & & \\
6.250 & 45.33 & $\mathrm{R} 2=0.8963$ & & \\
12.50 & 68.39 & & \\
25.00 & 74.75 & & \\
50.00 & 51.69 & & \\
\hline
\end{tabular}

The results of the study indicate that the antioxidant inhibition of free radicals by the tested samples increased with increasing concentration of the relevant extract in the samples. The results showed that in general, the plant extracts had significant antioxidant activity with $\mathrm{IC}_{50}$ values of less than $50 \mathrm{ppm}$. The results suggest the plant species used by the Kutai community for medicinal purposes have significant antioxidant activity, a property which may be part of the explanation for the reputed curative efficacy of plant extracts from these species. 


\subsection{Antioxidant activity}

Many traditional medicines derived from plants are identified as having anti-microbial activity. One standard method for preliminary testing of such antibiotic activity is to determine whether extracts of the medicinal plant can inhibit the growth of bacterial and fungi.

In this research, The plants extract were tested at four different concentrations for their efficacy in inhibiting the growth of bacterial (Streptococcus mutans, Streptococcus sobrinus, Escherichia coli, Propionibacterium acne) and fungi (Candida albicans) cultured on a Nutrient Broth medium in petri dishes. The results of the assay are summarized in Table 5.

Table 5 The Results of Antibacterial dan Antifungi Testing from Hippobroma longiflora (L) G. Don

\begin{tabular}{|c|c|c|c|c|c|}
\hline \multirow{2}{*}{ Bacterial/ Fungi } & \multicolumn{5}{|c|}{$\begin{array}{l}\text { Average of Inhibiton } \\
\text { Diameter (mm) }\end{array}$} \\
\hline & $\begin{array}{l}\text { Control } \\
+ \\
\end{array}$ & $\begin{array}{l}25 \\
(\mu g)\end{array}$ & $\begin{array}{l}50 \\
(\mu g)\end{array}$ & $\begin{array}{l}100 \\
(\mu \mathrm{g})\end{array}$ & $\begin{array}{l}200 \\
(\mu \mathrm{g})\end{array}$ \\
\hline $\begin{array}{l}\text { Streptococcus } \\
\text { mutans }\end{array}$ & 35.56 & 14.45 & 15.78 & 17.56 & 19.45 \\
\hline Streptococcus sobrinus & 37.67 & 13.34 & 16.46 & 18.44 & 20.44 \\
\hline $\begin{array}{l}\text { Escherichia } \\
\text { coli }\end{array}$ & 31.00 & 15.78 & 17.89 & 19.44 & 20.67 \\
\hline Propionibacterium acne & 32.67 & 10.00 & 14.55 & 17.78 & 18.89 \\
\hline $\begin{array}{l}\text { Candida } \\
\text { albicans }\end{array}$ & 27.00 & 3.33 & 14.11 & 15.22 & 16.78 \\
\hline
\end{tabular}

The extent of the bacterial inhibition zone for each of plants extract was greater at higher concentrations of the extract. A classification of strong inhibitory activity is given if the width of the zone of inhibition exceeds $6 \mathrm{~mm}$, a classification of moderate inhibitory activity if the zone is 3-6 mm, and of weak inhibitory activity if the zone is $0-3 \mathrm{~mm}$ in extent [26]. The results of antibacterial and antifungal activity testing showed that in general plant extracts were able to provide obstacles to the development of bacteria and fungi, namely strong and very strong. Weak inhibition is only shown in the Candida albicans fungus which is $3.3 \mathrm{~mm}$ at a concentration of $25 \mu \mathrm{g}$.

The results suggest that leaf extracts Hippobroma longiflora (L) G. Don have antibacterial potential presumably because of the phytochemically active compounds they contain. It is suspected that the antibacterial activity of the leaf extracts is due to the presence of secondary metabolite components such as terpenoids, steroids, saponins, tannins, and flavonoids [27]. The extent of the antibacterial effect may vary with the way the particular extraction method influences the stability and effectiveness of these active compounds.

\section{Conclusion}

Medicinal plant species traditionally used by the Kutai Ethnic in East Kalimantan (Indonesia) have been identified as containing bio-active compounds that are potentially beneficial in treating various diseases afflicting humans. The presence of phytochemicals compounds such as alkaloids, flavonoids, tannins, saponins, and steroids was detected in most extracts from the species. Samples were shown to have significant antioxidant activity and the results of the toxicity assay showed that samples were toxic. The antibacterial and antifungi testing generally showed the medicinal plants have a strong and very strong inhibitory effect on the growth of bacterium and fungi colonies. 


\section{Compliance with ethical standards}

\section{Acknowledgments}

This paper reports a small part of the results of research funded by the Program for Doctoral Dissertation Grants, of the Directorate of Research and Community (DP2M), Directorate General of Higher Education; Ministry of Research, Technology and Higher Education, contract number - 058/SP2H/LT/ DPRM/IV/2017, 25 April 2017. The authors wish to convey sincere thanks for the funding support given. We also thank colleagues and all those who supported this research.

\section{Disclosure of conflict of interest}

The author declared no conflict of interest.

\section{References}

[1] Bioresearcher. (2013). Indonesian Biodiversity Potential.

[2] Wahyuono S. (2012). Bioactive Evaluation of Medical Plants Colleted From Central Kalimantan. Bagian Biology Pharmacy Department, Faculty of Pharmacy, University of Gadjah mada, Yogyakarta.(Indonesian).

[3] Kähkönen MP, Hopia AI, Vuorela HJ, Rauha JP, Pihlaja K, Kujala TS and Heinonen M. (1999). Antioxidant activity of plant extracts containing phenolic compounds. J Agric Food Chem, 47(10), 3954-3962.

[4] Mammadov R, Ili P and Ertem-Vaizogullar H. (2011). Antioxidant activity and total phenolic content of Gagea fibrosa and Romulea ramiflora. Iran J Chem Chem Eng, 30(3), 57-62.

[5] Sampurno. (2007). Policy of Indonesian natural medicine development. 13th National Seminar on Indonesian Medicinal Plants. Pancasila University, Jakarta. [Indonesian].

[6] Achmad H. (1990). Traditional treatment of rural communities in East Kalimantan. Project Inventory and Cultural Values Development. Project Final Report. Directorate of History and Traditional Values, Directorate General of Culture, Ministry of Education and Culture, Jakarta [Indonesian].

[7] Arunkumar S and Muthuselvam M. (2009). Analysis of phytochemical constituents and antimicrobial activities of Aloe vera L. against clinical pathogens. World J Agric Sci, 5(5), 572-576.

[8] Kokate CK. (2001). Pharmacognosy. 16th ed. Nirali Prakasham, Mumbai, India.

[9] Harborne JB. (2006). Phytochemical Methods, A Guide to Modern Techniques of Plant Analysis. Springer, Netherlands.

[10] Meyer BN, Ferrigni NR, Putman JE, Jacobson LB, Nichols DE and McLaughlin JL. (1982). Brine shrimp: a convenient general bioassay for active plant constituents. Planta Medica, 45(5), 31-34.

[11] Boyd CE. (2005). LC50 calculations help predict toxicity. Global Aquacult Advoc, 84-87.

[12] Wagner SL. (1993). Quarterly Report ofEPA Grant \#CR-821022-01, luly l, 1993 September. 30, 1993. National Pesticide Medical Monitoring Program. Oregon State University, Corvallis.

[13] Arung ET, Muladi S, Sukaton E, Shimizu K and Kondo R. (2008). Artocarpin, a promising compound as whitening agent and anti-skin cancer. J Trop Wood Sci Technol, 6, 33-36.

[14] Jun M, Fu HY, Hong J, Wan X, Yang CS and Ho CT. (20030. Comparison of antioxidant activities of isoflavones from kudzu root (Pueraria lobata Ohwi). J Food Sci, 68(6), 2117-2122.

[15] Cappucino JG and Sherman N. (2001). Microbiology: A Laboratory Manual. 2nd Edition. The Benjamin Cummings Publishing Company. Rockland Community College, State University of New York, New York.

[16] Hanani E, Mun'im A and Sekarini R. (2005). Identifikasi senyawa antioksidan dalam spons Callyspongia sp. dari Kepulauan Seribu. Majalah Ilmu Kefarmasian, 2(3), 127-133.

[17] Evans WC. (2009). Trease and Evans' Pharmacognosy. 16th ed., Saunders Ltd., Edinburgh, UK.

[18] Okwu DE and Ndu CU. (2006). Evaluation of the phytonutrients, mineral and vitamin contents of some varieties of yam. Intl J Mol Med Adv Sci, 12(2), 199-203. 
[19] Igwenyi IO, Offor CE, Ajah DA, Nwankwo OC, Ukaomah JI and Aja PM. (2011). Chemical composition of Ipomoea aquatica (green kangkong). Intl J Pharm Biol Sci, 2(4), 593-598.

[20] McLaughlin JL, Chang CJ and Smith DL. (1993). Simple bench-top bioassays (brine shrimp and potato disk) for the discovery of plant antitumor compounds - Review of recent progress. In: Kinghorn AD, Baladrin MF. (eds). Human Medicinal Agents from Plants, Symposium Series No. 534, American Chemical Society, New York.

[21] Dvorak P, Benova K, Žd'arsky M, Sklenar Z and Havelkova A. (2010). Use of the crustacean Artemia franciscana for alternative biotests. Acta Vet Brno 79 (Suppl. 9), 47-53.

[22] McLaughlin. (1991). A Blind Coparison of Simple Bench - top Bioassay and Human Tumour Cel Citotoxicities as Antitumor Prescreens, Natural Product Chemistry, Elsivier, Amsterdam, 1

[23] Cefarelli G, Abrosca BD, Fiorentino A, Izzo A, Mastellone C, Pacifica S and Piscopo V. (2006). Free-radical scavenging and antioxidant activities of secondary metabolites from reddened cv. Annurca apple fruits. J Agric Food Chem, 54(3), 803-809.

[24] Ebrahimzadeh MA, Nabavi SF and Nabavi SM. (2009). Essential oil composition and antioxidant activity of Pterocarya fraxinifolia. Pak J Biol Sci, 12, 957-963.

[25] Saeed N, Khan MR and Shabbir M. (2012). Antioxidant activity, total phenolic and total flavonoid contents of whole plant extract Torilis leptophylla L. BMC Compl Altern Med, 12, 221.

[26] Pan X, Chen F, Wu T, Tang H and Zhao Z. (2009). The acid, bile tolerance and antimicrobial property of Lactobacillus acidophilus NIT. Food Control, 20(6), 598-602.

[27] Sulastrianah Imran and Fitria ES. (2014). Inhibitory test of leaf extracts (Annona muricata L.) and sirih (Piper betle L.) against the growth of Escherichia coli bacteria. Medula 1(2).

\section{How to cite this article}

Zarta AR, Aryani F, Salusu HD, Suwinarti W, Kusuma IW and Arung ET. (2020). Bioactivities of forest medicinal plants on kutai ethnic (Indonesia) of tapak leman (Hippobroma longiflora (L) G. Don). GSC Biological and Pharmaceutical Sciences, 11(2), 91-98. 